\title{
Measuring and simulating leaching of nutrients from a calcareous soil amended with sewage sludge and poultry manure
}

\author{
farhad mazloomi ${ }^{1}$ and Mohsen Jalali ${ }^{1}$ \\ ${ }^{1} \mathrm{Bu}$ Ali Sina University
}

June 15, 2020

\begin{abstract}
Leaching of nutrients due to the application of sewage sludge and poultry manure is a major problem in intensive farming. Simulating helps assess the nutrient loss and establish better methods for fertilization. This study was conducted to investigate the leaching of nutrients (NH4-N, NO3-N, Na, K, Ca, and Mg) from soils amended with different rates (1\%,3\%, and 5\%) of sewage sludge and poultry manure. The breakthrough curves of cations were also simulated by the PHREEQC program. The addition of sewage sludge and poultry manure to the soil columns increased the leaching of nutrients compared to the control soil. For all soil columns, the highest concentrations of leached nutrients were observed in the first leachate and decreased exponentially over time. Regardless of the amount of amendments applied, the percentage (the proportion of cumulative nutrient leached relative to the exchangeable one) of cumulative leaching losses of NO3-N, Na, K, Ca and Mg were significantly higher, while NH4-N was lower from poultry-amended soils than sewage sludge-amended soils. Based on the results, more attention should be paid to the potential risk of soil nutrient leaching especially NH4-N, K and NO3-N posed after applying sewage sludge and poultry manure, respectively. The simulation results indicated that predicting breakthrough curves of NH4$\mathrm{N}, \mathrm{K}$, and $\mathrm{Ca}($ mean NRMSE $<1$ ) by the PHREEQC program was better than $\mathrm{Mg}$ and $\mathrm{Na}($ mean NRMSE $>1)$ and cation exchange was the main mechanism to control the concentrations of cations in the leachates.
\end{abstract}

\section{Introduction}

World population growth and increasing demand for food have led to excessive use of land for agriculture, a sharp decrease in soil nutrients, and consequently a diminish in the soil fertility and quality of agricultural products. The application of chemical and organic fertilizers is recommended to compensate for soil nutrients. The use of chemical fertilizers is the fastest and most reliable way to improve soil fertility and macronutrients, such as nitrogen $(\mathrm{N})$ and phosphorus $(\mathrm{P})$. However, chemical fertilizers contribute to the non-point source $\mathrm{N}$ and $\mathrm{P}$ losses, which increase water and soil pollution, soil acidification, and accelerate eutrophication. Leaching of nutrients from the soil to groundwater is caused by several factors, such as environmental conditions, soil physical and chemical properties, agricultural activities, and chemical and organic fertilizer application (Li et al., 2016). The application of organic fertilizers with the optimum rate of chemical fertilizers is recommended for improving soil fertility, soil structure, and activity of the organisms. Organic farming systems that rely on the use of organic matter and the lack of use of chemical fertilizers are expanding because it is environmentally friendly and improve the quality of soil and water in comparison with modern agricultural systems. Various types of organic amendments (sewage sludge, animal manures, plant residues, biochar, etc.) are used to improve the physical, chemical, and biological properties of soil. Sewage sludge is an inexpensive and nutritious organic fertilizer that is widely used in agricultural land (Opiony et al., 1998; Brady \& Weil, 2012). In many countries, the banning of sewage sludge disposal by burial and the lack of suitable landfill has increased the application of sewage sludge in agricultural land. One of the advantages of using sewage sludge in agriculture is the return of essential nutrients and organic matter to soil (Brockway, 
1983; Bramayard, 2002). Poultry manure, such as sewage sludge, is suggested as a source of nutrients in some research (Sharplley et al., 2004) and high concentrations of macronutrients have been reported in these organic manures. But there is concern about the presence of organic and inorganic pollutants in sewage sludge and poultry manure. The nutrients and pollutants in the sewage sludge and poultry manure can be leached when they enter the soil and cause pollution of groundwater ( $\mathrm{Li}$ et al., 2016). Agriculture is one of the primary sources of water pollution and farmers must adopt sustainable practices to maintain optimum water quality in line with international standards (Thorburn et al., 2003; Jalali, 2005; Islam et al., 2011). Water conservation, while maintaining the function of living systems, is a major challenge for the agriculture industry (Elmi et al., 2005). Leaching of nutrients is an important environmental concern because the high concentrations of some ions in drinking water are harmful to human and aquatic ecosystem health (Jalali \& Martipurpour, 2008). Excessive application of organic and inorganic fertilizers in agricultural lands causes $\mathrm{N}$ leaching and other nutrients into surface and groundwater. Leaching of nitrate $\left(\mathrm{NO}_{3}-\mathrm{N}\right)$ in soils treated with $\mathrm{N}$-rich fertilizers and organic fertilizers is a serious concern that has been considered in many investigations (Shephard, 1996; Corrêa et al., 2006; Samaras et al., 2008; Shepherd and Newell-Price, 2013; Forge et al., 2016). However, ammonium $\left(\mathrm{NH}_{4}-\mathrm{N}\right)$ leaching in soils amended with organic and inorganic fertilizers has received little attention in research. There is also limited knowledge about the leaching of the main nutrients in sewage sludge and poultry manure, such as sodium $(\mathrm{Na})$, potassium $(\mathrm{K})$, calcium $(\mathrm{Ca})$, and magnesium (Mg) (Medalie et al., 1994; McLaren et al., 2003). Although Ca, Mg, and K nutrients have low environmental and harmful effects on human and animal health, but their leaching from soil causes the loss of valuable nutrients as well as the beneficial potential of sewage sludge for agriculture. Simulation of nutrient leaching using models provides an opportunity to estimate nutrients leaching and to help to explain the changes observed during leaching while reducing or eliminating field measurement costs (Ingraham \& William, 2019). The PHREEQC program is a computer program to simulate chemical reactions and transport processes in soil and has been used by many researchers (Jalali \& Latifi, 2018; Mazloomi \& Jalali, 2017; Embile et al., 2019). A clear understanding of the potential leaching risk of nutrients from organic amended soils is needed so that management practices can be modified to protect water quality. Therefore, this study was carried out to investigate leaching of $\mathrm{NH}_{4}-\mathrm{N}, \mathrm{NO}_{3}-\mathrm{N}, \mathrm{Na}, \mathrm{K}, \mathrm{Ca}$, and $\mathrm{Mg}$ in soil columns amended with $1 \%, 3 \%$, and $5 \%$ of sewage sludge and poultry manure. The cations breakthrough curves were also simulated by the PHREEQC software.

\section{Materials and Methods}

\section{Soil and organic amendments}

The sandy loam soil used in this study was collected from $0-20 \mathrm{~cm}$ depths of the soil layers in the Azandarian area, Hamadan, western Iran (Table 1). In this area, various crops and horticultural products, including grapes, wheat, vegetables, and forage are cultivated. Two types of organic amendments (sewage sludge and poultry manure) were widely used to increase soil fertility in Iran. Sewage sludge was collected from the wastewater treatment plant, Toyserkan, Hamedan, and poultry manure were purchased from the Netherlands. Farmers in Hamedan and Iran provide a significant portion of the organic fertilizers from imported fertilizers. Both organic fertilizers were air-dried, passed through a $2 \mathrm{~mm}$ sieve, and kept to measure their physical and chemical properties. The total N (Kjeldahl N) was measured by the Hess method (Hess, 1971). Electrical conductivity (EC) and $\mathrm{pH}$ of organic amendments were measured after extraction with distilled water (1:5 $\mathrm{w} / \mathrm{v}$ organic amendments to water extract). Concentrations of $\mathrm{NH}_{4}-\mathrm{N}$ and $\mathrm{NO}_{3}-\mathrm{N}$ in organic amendments were extracted by $1 \mathrm{M} \mathrm{KCl} \mathrm{(1:10} \mathrm{w/v} \mathrm{organic} \mathrm{amendments} \mathrm{to} \mathrm{water} \mathrm{ratio)} \mathrm{and} \mathrm{determined} \mathrm{colorimetrically}$ (Mulvaney, 1996). These extracted $\mathrm{N}$ forms may represent the available $\mathrm{N}$. Organic amendments samples were digested in nitric acid (1:20 w/v organic amendments to nitric acid ratio) for extraction of total basic cations. Total $\mathrm{Ca}$ and $\mathrm{Mg}$ were determined by the titration method and total $\mathrm{K}$ and $\mathrm{Na}$ were measured by flame photometry (Hess, 1971). Characteristics of organic sewage sludge and poultry manure are shown in Table 2. The exchangeable cations $(\mathrm{Ca}, \mathrm{Mg}, \mathrm{K}$ and $\mathrm{Na}$ ) in sewage sludge and poultry manure were extracted using $1 \mathrm{~N}$ ammonium acetate $\left(\mathrm{NH}_{4} \mathrm{OAc}\right)$. The exchangeable cations in the soil before and after the addition of different rates of sewage sludge and poultry manure are given in Table 3 (exchangeable $\mathrm{Ca}, \mathrm{Mg}, \mathrm{K}$ and $\mathrm{Na}$ were calculated from the sum of cation exchange capacity (CEC) of soil and organic amendments, and 
exchangeable $\mathrm{NH}_{4}-\mathrm{N}$ was measured by extraction with $1 \mathrm{M} \mathrm{KCl}$ in amended soils). Soil solution properties ( $\mathrm{pH}, \mathrm{EC}$, and concentrations of cations) in the control soil and sewage sludge and poultry manure-amended soils were extracted using distilled water $(1: 1 \mathrm{w} / \mathrm{v}$ soil to water ratio), as well as the concentration of available $\mathrm{NO}_{3}-\mathrm{N}$ by $1 \mathrm{M} \mathrm{KCl}$ was extracted (Table 3). The concentration of $\mathrm{NO}_{3}-\mathrm{N}$ was measured colorimetrically.

\section{Leaching experiments}

The collected soil was air-dried and passed through a $2 \mathrm{~mm}$ sieve. Different rates $(1 \%, 3 \%$, and $5 \%$ ) of sewage sludge and poultry manure were mixed homogeneously and manually with soil. Farmers usually add a lot of organic amendments to increase their crop yield, which is more than the amount needed for the yield improvement. Therefore, different rates of sewage sludge and poultry manure were used in this experiment to compare the leaching of nutrients and the risks of groundwater pollution with real conditions. The mixtures of soil and organic amendments were placed into columns consisting of Pyrex tubes, $30 \mathrm{~cm}$ in length and an internal diameter of $4.9 \mathrm{~cm}$. The height and bulk density of the soil inside the columns were $10 \mathrm{~cm}$ and $1.67 \mathrm{~g} / \mathrm{cm}^{3}$, respectively. The soils were kept at the end of the column by a Whatman no. 42 filter paper, which was supported by a nylon mesh base. To prevent the dispersion of surface soil, a filter paper was placed on the soil surface of the column. Distilled water was used for leaching of nutrients from columns. Soil columns were incubated at room temperature for 20 days and irrigated daily with distilled water. The leaching experiments were carried out in two replications and a total of 14 leaching columns were set up. The leachates were collected daily and stored at $2 \operatorname{deg} \mathrm{C}$ for measurement of $\mathrm{pH}, \mathrm{EC}, \mathrm{NH}_{4}-\mathrm{N}_{1} \mathrm{NO}_{3}-\mathrm{N}, \mathrm{Na}, \mathrm{K}$, $\mathrm{Ca}$, and $\mathrm{Mg}$ parameters. The $\mathrm{pH}$ and $\mathrm{EC}$ of leachates were measured using $\mathrm{pH}$ and electrical-conductivity meters, respectively. Concentrations of $\mathrm{NH}_{4}-\mathrm{N}$ and $\mathrm{NO}_{3}-\mathrm{N}$ in leachates were determined colorimetrically (Mulvaney, 1996). The concentration of $\mathrm{Ca}$ and $\mathrm{Mg}$ were determined by the titration method and $\mathrm{K}$ and $\mathrm{Na}$ were measured by flame photometry (Hess, 1971).

\section{Simulation of cations leaching by PHREEQC program}

For the simulation of leaching of $\mathrm{NH}_{4}-\mathrm{N}, \mathrm{Na}, \mathrm{K}, \mathrm{Ca}$, and $\mathrm{Mg}$ in the control and sewage sludge and poultry manure-amended soils, the PHREEQC program (Parkhurst \& Appelo, 2013) was used. The parameters applied for simulation of cations leaching included the concentrations of cations in soil solution, the values of CEC, the values of selectivity coefficients for the exchange of different cations with exchange sites, soil column characteristics (such as length of soil columns and leaching time). The selectivity coefficients values (Table 4) applied in the leaching simulation were determined based on the change of database coefficients and the best fit to the measured data (Jalali \& Latifi, 2018). The cation exchange capacity of the soil and organic amendments were measured separately and the CEC values used in the simulation were calculated based on the sum of soil and organic amendments CEC. The soil solution properties of control and amended soils were also measured in the laboratory and used for simulation. The determination coefficient $\left(\mathrm{r}^{2}\right)$, rootmean-square error (RMSE), and normalized root-mean-square error (NRMSE) were used to evaluate the performance of the cation exchange model in PHREEQC program (Xiong et al., 2006; Mazloomi and Jalali, 2019).

\section{Results and Discussion \\ 2. Electrical conductivity changes in soil leachates}

Fig. 1a indicates the EC leachate for different treatments. The results showed that the application of sewage sludge and poultry manure increased leachate EC compared to the control soil. Also, increasing the rates of both amendments increased leachate EC. The leachate EC was very high on the first day in all soil columns and exponentially decreased on the second day until a steady trend on the 20th day. Values of leachate EC in soil columns amended with different rates of poultry manure were higher than sewage sludge. Poultry manure and sewage sludge contain high soluble salts and therefore their application in soil increased soil solutes and thus increased EC. When the solutes of the soil are leached and the balance between the soil solution and the exchangeable sites is achieved, the value of leachate EC reaches a constant trend (Civeira \& Lavado, 2008). Many researchers have reported that the use of different organic amendments increase the concentration of soil solutes and thus increases the EC in the soil, which is consistent with the results of 
the present study (Gallardo-Lara \& Nogales, 1987; Selvakumari et al., 2000; Niklasch \& Joergensen, 2001; Atiyeh et al., 2001; Sarwar et al., 2003; Gonzalez et al., 2010; Angelova et al., 2013).

\section{$\mathrm{pH}$ changes in soil leachates}

The results showed that the leachate $\mathrm{pH}$ in the control soil fluctuated in the range of 7.70 to 8.12 and the mean of leachate $\mathrm{pH}$ during the leaching period was 7.93 (Fig. 1b). The application of sewage sludge and poultry manure decreased leachate $\mathrm{pH}$ compared to control soil. Mean leachate $\mathrm{pH}$ in soil columns amended with $1 \%, 3 \%$, and $5 \%$ of sewage sludge and poultry manure were $7.64,7.56,7.47,7.64,7.48$, and 7.46 , respectively. Adding organic matter to soil buffers soil $\mathrm{pH}$ changes. Soil organic matter has many negative sites that bond with hydrogen ion in acidic soils and release hydrogen ion in basic soils and this mechanism neutralizes $\mathrm{pH}$ in both soil types. Organic residues usually contain large amounts of ions and their decomposition initially causes a temporary increase in soil $\mathrm{pH}$. The soil microorganisms during the decomposition of plant residues into $\mathrm{NH}_{4}-\mathrm{N}$ cause a temporary increase in $\mathrm{pH}$. The conversion of $\mathrm{NH}_{4}-\mathrm{N}$ to $\mathrm{NO}_{3}-\mathrm{N}$ by the nitrification process reduces $\mathrm{pH}$. If the $\mathrm{NO}_{3}-\mathrm{N}$ is lost during the leaching process, the $\mathrm{pH}$ will show an even greater reduction. The effects of organic matter on soil $\mathrm{pH}$ depend on the processes of production and loss of $\mathrm{N}$ (leaching into the soil and uptake by the plant), the quantity and quality of soil organic matter and the initial $\mathrm{pH}$ (Pocknee \& Sumner, 1997; Paul et al., 2003; Butterly et al., 2013). Angelova et al. (2013) indicated that organic acid (amino acids, glycine, cysteine, and humic acid) production during the process of mineralization of organic matter by heterotrophic microorganisms and nitrification by autotrophic bacteria decrease soil $\mathrm{pH}$.

\section{Leaching of $\mathrm{NH}_{4}-\mathrm{N}$}

The breakthrough curves and the cumulative amount of $\mathrm{NH}_{4}-\mathrm{N}$ leached from control soil and soils amended with $1 \%, 3 \%$, and $5 \%$ of sewage sludge and poultry manure are shown in Fig. 2a. The results showed that the concentration of $\mathrm{NH}_{4}-\mathrm{N}$ in the leachate from the control soil was $0.5 \mathrm{mg} / \mathrm{L}$ on the first day and decreased exponentially over time. Low $\mathrm{NH}_{4}-\mathrm{N}$ concentration in the control soil may be due to the low content of organic matter and low release of $\mathrm{NH}_{4}-\mathrm{N}$ by mineralization of organic matter. Also applied $\mathrm{NH}_{4}{ }^{-}$ $\mathrm{N}$ fertilizers in light-textured soils are rapidly converted to $\mathrm{NO}_{3}-\mathrm{N}$ by nitrification process because these soils have sufficient ventilation. Therefore, low concentrations of $\mathrm{NH}_{4}-\mathrm{N}$ in control soil leachate were expected. $\mathrm{Di}$ and Cameron (2005) indicated that $\mathrm{NH}_{4}-\mathrm{N}$ leaching rarely occurs in soil because the concentration of $\mathrm{NH}_{4}-\mathrm{N}$ in most surface soils is low and is maintained by exchange sites. Application of sewage sludge and poultry manure increased $\mathrm{NH}_{4}-\mathrm{N}$ leaching compared to control soil. The concentration of $\mathrm{NH}_{4}-\mathrm{N}$ on the first day in soils amended with rates of $1 \%, 3 \%$, and $5 \%$ of sewage sludge and poultry manure were 21.2 , $72.0,207.9,11.1,46.8$ and $91.2 \mathrm{mg} / \mathrm{L}$, respectively, and decreased exponentially over time. An exponential decrease in $\mathrm{NH}_{4}-\mathrm{N}$ concentration over time may be due to the reduction in $\mathrm{NH}_{4}-\mathrm{N}$ concentration in the soil solution phase, oxidation of $\mathrm{NH}_{4}-\mathrm{N}$ to $\mathrm{NO}_{3}-\mathrm{N}$, and adsorption of residual $\mathrm{NH}_{4}-\mathrm{N}$ by soil exchange sites (Qiang et al., 2004). Soil columns amended with sewage sludge had high values of $\mathrm{NH}_{4}-\mathrm{N}$ leaching on day 10 to the end of the leaching due to lower $\mathrm{C} / \mathrm{N}$ ratio of sewage sludge, higher total $\mathrm{N}$ content and possibly greater mineralization of sewage sludge compared to poultry manure. The cumulative amounts of $\mathrm{NH}_{4}-\mathrm{N}$ leached in soil columns amended with sewage sludge were significantly higher than poultry manure (Table 5). The results also showed that in control soil and soils amended with $1 \%, 3 \%$, and $5 \%$ of sewage sludge and poultry manure, the cumulative amounts of $\mathrm{NH}_{4}-\mathrm{N}$ leached was equal to $14.4 \%, 87.3 \%, 131.4 \%, 133.1 \%$, $33.1 \%, 55.7 \%$ and $67.1 \%$ of soil exchangeable $\mathrm{NH}_{4}-\mathrm{N}$, respectively. In soil columns containing $3 \%$ and $5 \%$ sewage sludge, the amount of $\mathrm{NH}_{4}-\mathrm{N}$ leached from soil was higher than exchangeable $\mathrm{NH}_{4}-\mathrm{N}$, probably due to the decomposition of organic residues and release of $\mathrm{NH}_{4}-\mathrm{N}$ by mineralization process. Zarabi and Jalali (2012) investigated $\mathrm{NH}_{4}-\mathrm{N}$ leaching in some native calcareous soils and their results showed that the cumulative amounts of $\mathrm{NH}_{4}-\mathrm{N}$ leached were $0.8-7.4 \mathrm{mg} / \mathrm{kg}$. They also reported that the cumulative amount of $\mathrm{NH}_{4}-\mathrm{N}$ leached was about $14.1 \%-143.8 \%$ of the exchangeable $\mathrm{NH}_{4}-\mathrm{N}$ in different soils. Many researchers have reported that $\mathrm{NH}_{4}-\mathrm{N}$ leaching is high in light-textured soils treated with organic residues because these soils have low CEC and high hydraulic conductivity (Deare et al., 1995; Li et al., 1997; Gundersen, 1998; Pathan et al., 2002; Zarabi \& Jalali, 2012). Also when the soil exchange sites are saturated and large amounts of $\mathrm{NH}_{4}-\mathrm{N}$ fertilizers enter the soil or in adverse environmental conditions where nitrification is low 
in the soil, $\mathrm{NH}_{4}-\mathrm{N}$ leaching increases (Wang \& Battany, 1995; Wang \& Zhang, 2004; Herrmann et al., 2005; Haynes and Judge, 2008). Oren et al. (2003) reported that high concentrations of soluble salts and high $\mathrm{pH}$ in the soil are the main factors preventing the oxidation of $\mathrm{NH}_{4}-\mathrm{N}$ and nitrite $\left(\mathrm{NO}_{2}-\mathrm{N}\right)$, which increases $\mathrm{NH}_{4}-\mathrm{N}$ leaching in the soil. Some studies have reported that $\mathrm{NH}_{4}-\mathrm{N}$ leaching from soils treated with sewage sludge and a variety of livestock manure was negligible (Medalie et al., 1994; Cameron et al., 1995; Cameron et al., 1996; Carey et al., 1997), which is contrary to the results of the present study. The cause of the contradiction between the present study and other researches may be due to differences in soil texture, type of organic residues, amount of $\mathrm{NH}_{4}-\mathrm{N}$ in the organic residues, degree of decomposition of organic residues, and duration of leaching. There were positive correlations (Table 6) between cumulative $\mathrm{NH}_{4}-\mathrm{N}$ leaching losses and exchangeable $\mathrm{NH}_{4}-\mathrm{N}, \mathrm{Ca}$, and $\mathrm{Mg}$, while positive correlations were found with solution $\mathrm{NH}_{4}-\mathrm{N}$, $\mathrm{NO}_{3}-\mathrm{N}$, and $\mathrm{Mg}$ in the control and amended soil.

\section{Leaching of $\mathrm{NO}_{3}-\mathrm{N}$}

The breakthrough curve and the cumulative amount of $\mathrm{NO}_{3}-\mathrm{N}$ leached are shown in Fig. 2b. The concentration of $\mathrm{NO}_{3}-\mathrm{N}$ in the control soil in the first leachate was $14 \mathrm{mg} / \mathrm{L}$ and decreased to less than $10 \mathrm{mg} / \mathrm{L}$ over time. The rapid movement of $\mathrm{NO}_{3}-\mathrm{N}$ ions in the soil is due to the repulsive force between the $\mathrm{NO}_{3}-\mathrm{N}$ anion and the negative charge particles in the soil. Zarabi and Jalali (2012) investigated $\mathrm{NO}_{3}-\mathrm{N}_{\text {leaching }}$ in some native calcareous soils with different textures. Their results showed that the $\mathrm{NO}_{3}-\mathrm{N}$ concentration was high in the first leachate and in the subsequent leachates the $\mathrm{NO}_{3}-\mathrm{N}$ concentration was significantly reduced, which is in agreement with the results of the present study. Razzaque and Hanafi (2004) reported that $\mathrm{NO}_{3}-\mathrm{N}$ concentration in the first leachate of peat soil was $13 \mathrm{mg} / \mathrm{L}$ and decreased abruptly. Application of sewage sludge and poultry manure amendments increased $\mathrm{NO}_{3}-\mathrm{N}$ leaching. Concentrations of $\mathrm{NO}_{3}-\mathrm{N}$ in the first leachate in columns amended with $1 \%, 3 \%$, and $5 \%$ of sewage sludge and poultry manure were 32.5 , $65.7,125.1,45.3,150.2$ and $347.6 \mathrm{mg} / \mathrm{L}$, respectively. Nitrate concentration in poultry manure was higher than sewage sludge, so $\mathrm{NO}_{3}-\mathrm{N}$ leaching was higher in the presence of poultry manure as expected. Nitrate concentration in all soil columns reached equilibrium after about 10 days. High levels of $\mathrm{NO}_{3}-\mathrm{N}$ in leachate even after 20 days indicate the possibility of groundwater contamination with high rates of sewage sludge and poultry manure. The cumulative amount of $\mathrm{NO}_{3}-\mathrm{N}$ leached in control soil and soil columns amended with $1 \%, 3 \%$ and $5 \%$ of sewage sludge and poultry manure were $9.3,25.9,39.4,62.5,27.8,75.4$ and 173.9 $\mathrm{mg} / \mathrm{kg}$, respectively and significantly higher amounts of $\mathrm{NO}_{3}-\mathrm{N}$ was leached from soil amended with $5 \%$ poultry manure (Table 5). The results also showed that in the control soil and soils amended with 1\%, $3 \%$ and $5 \%$ of sewage sludge and poultry manure, the amounts of $\mathrm{NO}_{3}-\mathrm{N}$ leached was equal to $94.0 \%, 123.3 \%$, $121.2 \%, 123.4 \%, 104.6 \%, 128.9 \%$ and $150.2 \%$ of available $\mathrm{NO}_{3}-\mathrm{N}$, respectively. Nitrate in the soil is readily transported by diffusion and mass flow process, so a large proportion of $\mathrm{N}$ fertilizers are exposed to leaching. Groundwater contamination by $\mathrm{NO}_{3}-\mathrm{N}$ has been reported by many researchers as a result of the overuse of organic fertilizers )Tong et al., 1997; Gonzalez et al., 2009; Masaka et al., 2013; Aronsson et al., 2014; Parvage et al., 2015). Gonzalez et al. (2009) reported a high concentration of $\mathrm{NO}_{3}-\mathrm{N}$ in leachate in a study on soil treated with poultry manure. In this study, $\mathrm{NO}_{3}-\mathrm{N}$ leaching increased significantly with increasing the application rates of sewage sludge and poultry manure. Some researchers have reported that there is a positive relationship between the applied rate of fertilizers and the leaching of $\mathrm{NO}_{3}-\mathrm{N}$ (Gondek \& Konpee, 2009; Shepherd \& Newell-Price, 2013). One of the reasons for high $\mathrm{NO}_{3}-\mathrm{N}$ leaching in the present study is due to the sandy texture of the soil, which caused a large amount of $\mathrm{NO}_{3}-\mathrm{N}$ in sewage sludge and poultry manure to be leached from the soil columns. Shepherd and Newell-Price (2013) indicated that $\mathrm{NO}_{3}$ - $\mathrm{N}_{\text {leaching }}$ in soil was affected by soil texture and was higher in sandy soils. In sandy soils, $\mathrm{N}$ mineralization and $\mathrm{NO}_{3}-\mathrm{N}$ leaching are high because high temperatures and sandy soil texture increase the mineralization of organic $\mathrm{N}$. The effect of soil texture on $\mathrm{N}$ mineralization is due to the amount of clay (Breland \& Hansen, 1996). In soils with high clay content, a physical shield prevents the mineralization of organic matter (Stenger et al., 1995). Sadej (2009) indicated that the amount and dominant form of $\mathrm{N}$ leaching in soils amended with different types of sewage sludge and sewage sludge compost depends on the application rate, application method, and type of sewage sludge.

There were positive correlations (Table 6) between cumulative $\mathrm{NO}_{3}-\mathrm{N}$ leaching losses and exchangeable $\mathrm{Na}$ 
and EC, while positive correlations were found with solution $\mathrm{Na}, \mathrm{K}$, and $\mathrm{Ca}$ in the control and amended soil.

\section{Leaching of $\mathrm{Na}$ and $\mathrm{K}$}

The breakthrough curves of $\mathrm{Na}$ and the cumulative amounts of $\mathrm{Na}$ leached are shown in Fig. 3a. The results showed that in control and amended soils maximum concentration of $\mathrm{Na}$ was observed in the first leachate. The high concentrations of $\mathrm{Na}$ in the leachate of poultry manure-amended soils are due to the higher Na content in poultry manure compared to sewage sludge (Table 2). The concentration of $\mathrm{Na}$ in the leachate in all soil columns decreased exponentially until day 6-14 and after this time remained constant. The results showed that significantly higher amounts of Na were leached from soil amended with $3 \%$ and $5 \%$ poultry manure (Table 5). Cumulative amounts of $\mathrm{Na}$ leached in control soil and soil columns containing $1 \%, 3 \%$ and $5 \%$ sewage sludge and poultry manure were $2.6,9.5,23.3,38.9,41.7,125.8$ and $201.1 \mathrm{mg} / \mathrm{kg}$ (Table 5), corresponding to $1.9 \%, 6.9 \%, 14.5 \%, 24.2 \%, 25.9 \%, 60.8 \%$ and $79.5 \%$, respectively. There were positive correlations (Table 6) between cumulative Na leaching losses and exchangeable Na, while positive correlations were found with $\mathrm{pH}, \mathrm{EC}$, and solution $\mathrm{Na}, \mathrm{K}$, and $\mathrm{Ca}$ in the non-amended and amended soil.

The breakthrough curves of $\mathrm{K}$ and the cumulative amounts of $\mathrm{K}$ leached are shown in Fig. 3b. The results showed that a significant amount of $\mathrm{K}$ was leached from amended soils. Over time, $\mathrm{K}$ concentration in control and amended soils decreased exponentially and $\mathrm{K}$ concentration in the leachates in poultry manure amended-soils was higher than that of sewage sludge. The results showed that significantly higher amounts of $\mathrm{K}$ were leached from soil amended with $3 \%$ and $5 \%$ poultry manure (Table 5 ). The cumulative amounts of $\mathrm{K}$ leached in control soil and soils containing $1 \%, 3 \%$ and $5 \%$ of sewage sludge and poultry manure were $57.6,68.9,129.4,168.5,211.9,746.5,1123.4 \mathrm{mg} / \mathrm{kg}$ (Table 5), corresponding to $8.1 \%, 9.7 \%, 18.2 \%, 23.7 \%$, $29.8 \%, 100.5 \%$ and $158.6 \%$, of exchangeable $\mathrm{K}$, respectively. The poultry manure used in the present study was enriched by $\mathrm{K}$ fertilizer, so in the soils amended with $3 \%$ and $5 \%$ poultry manure the amount of leached exchangeable $\mathrm{K}$ was higher than the soil exchangeable K. Potassium leaching in the soil depends on the concentration of $\mathrm{K}$ in the soil solution, the type of soil clay minerals, the dry and wet conditions of soil, and the type of cations (especially $\mathrm{Ca}, \mathrm{Mg}$, and $\mathrm{Na}$ ) present in the solution (Evangelou \& Lumbanraja, 2002). The addition of various organic residues such as poultry manure and sewage sludge increases the concentration of $\mathrm{K}$ in the solution phase and thus increases its leaching (Adegbidi et al., 2003; Gonzalez et al., 2009). Adding these residues also increases the concentration of $\mathrm{Ca}, \mathrm{Mg}$, and $\mathrm{Na}$ in the soil and thus increases the release of $\mathrm{K}$ from the soil exchange sites. Jones et al. (2012) reported that the application of poultry manure increased the concentration of $\mathrm{Na}$ and $\mathrm{K}$ in soil solution, and $\mathrm{K}$ had a higher concentration than $\mathrm{Na}$ in leachate, which is consistent with the results of the present study. Zhang et al. (2004) investigated the effect of animal manure on EC and solute concentration in soil leachates. Their results showed that the application of high levels of animal manure increased the concentration of nutrients such as $\mathrm{Na}$ and $\mathrm{K}$ in the leachate, and the highest concentration of $\mathrm{Na}$ and $\mathrm{K}$ were observed in the first leachate. The addition of sewage sludge to soil also increases the leaching of $\mathrm{Na}$ and $\mathrm{K}$ into the soil because sewage sludge is the source of these cations (Medali et al., 1994; Mclaren et al., 2003; Ahlberg et al., 2006).

Like cumulative Na leached, there were positive correlations (Table 6) between cumulative K leaching losses and exchangeable $\mathrm{Na}$, while positive correlations were found with $\mathrm{pH}, \mathrm{EC}$, and solution $\mathrm{Na}$, $\mathrm{K}$, and $\mathrm{Ca}$ in the non-amended and amended soil, indicating the similarities between these ions.

\section{Leaching of $\mathrm{Ca}$ and $\mathrm{Mg}$}

The breakthrough curves and the cumulative amounts of $\mathrm{Ca}$ and $\mathrm{Mg}$ in control and amended soils are shown in Figs. 4. Application of amendments increased the concentration of $\mathrm{Ca}$ and $\mathrm{Mg}$ in the leachates and the leaching of both cations in all soil columns decreased exponentially over time. Increasing rates of amendments also increased the concentrations of $\mathrm{Ca}$ and $\mathrm{Mg}$ in the soil leachates. The results showed that the cumulative amounts of $\mathrm{Ca}$ and $\mathrm{Mg}$ leached in the columns treated with poultry manure were higher than the sewage sludge. The results showed that significantly higher amounts of Ca were leached from soil amended with $5 \%$ poultry manure (Table 5). The amounts of exchangeable Ca leached in the control soil and the soils amended with $1 \%, 3 \%$, and $5 \%$ of sewage sludge and poultry manure were $16.2 \%, 18.3 \%, 21.5 \%, 23.1 \%$, 
$16.4 \%, 23.5 \%$ and $25.7 \%$, respectively, and the amounts of exchangeable $\mathrm{Mg}$ leached in these treatments were $33.5 \%, 37.8 \%, 32.9 \%, 48.4 \%, 38.3 \%, 59.9 \%$ and $63.5 \%$, respectively. The trend of $\mathrm{Mg}$ concentration in leachate was similar to that of $\mathrm{Ca}$, and the same leaching trend is due to the similar behavior of these two cations in soil (Mclaren et al., 2003; Gonzalez et al., 2009). The results showed that significantly higher amounts of $\mathrm{Mg}$ were leached from soil amended with $3 \%$ and $5 \%$ poultry manure (Table 5 ). In some studies, the effects of organic residues on the leaching of $\mathrm{Ca}$ and $\mathrm{Mg}$ have been reported. Zhang et al. (2004) reported that animal manure application had a significant effect on the leaching of nutrients such as Ca and $\mathrm{Mg}$, and cumulative amounts of cations leached increased with the increasing rate of manure. Haynes and Judge (2008) investigated the effect of surface application of poultry manure $(0-5 \mathrm{~cm} \mathrm{depth})$ on nutrient and salinity leaching in soil columns, and measured nutrient concentrations in 4 leachate volumes on days 9, 37, 58 and 86 after the leaching. Their results showed that the addition of poultry manure increased the leaching of different nutrients such as $\mathrm{Ca}$ and $\mathrm{Mg}$ compared to control soil. Ahlberget al. (2006) investigated the leaching of various cations from surface soil treated with sewage sludge. Their results showed that soil treated with sewage sludge increased the leaching of nutrients such as $\mathrm{Ca}$ and $\mathrm{Mg}$ from the soil and the amount of $\mathrm{Ca}$ and $\mathrm{Mg}$ leached was equal.

There were positive correlations (Table 6) between cumulative Ca leaching losses and exchangeable $\mathrm{NH}_{4}-\mathrm{N}$, $\mathrm{K}, \mathrm{Ca}$, and $\mathrm{Mg}$, while positive correlations were found with $\mathrm{EC}$ and solution $\mathrm{NO}_{3}-\mathrm{N}, \mathrm{Ca}$, and $\mathrm{Mg}$ in the non-amended and amended soil. There were positive correlations (Table 6) between cumulative $\mathrm{Mg}$ leaching losses and exchangeable $\mathrm{Na}$, while positive correlations were found with $\mathrm{EC}$ and solution $\mathrm{Na}, \mathrm{K}$, $\mathrm{Ca}$, and $\mathrm{Mg}$ in the non-amended and amended soil.

In general, based on the proportion of cumulative nutrients leached relative to the exchangeable ones, the order of nutrients leached in sewage sludge-amended soils was $\mathrm{NH}_{4}-\mathrm{N}>\mathrm{NO}_{3}-\mathrm{N}>\mathrm{Mg}>\mathrm{Na}>\mathrm{K}>\mathrm{Ca}$, whereas the order for poultry-amended soils was $\mathrm{K}>\mathrm{NO}_{3}>\mathrm{Na}>\mathrm{NH}_{4}-\mathrm{N}>\mathrm{Mg}>\mathrm{Ca}$. Thus, more attention should be paid to the potential risk of soil nutrient leaching especially $\mathrm{NH}_{4}-\mathrm{N}$, and $\mathrm{K}, \mathrm{NO}_{3}-\mathrm{N}$ posed after application of sewage sludge and poultry manure, respectively.

\section{Simulation of cations leaching by PHREEQC program}

The measured and simulated breakthrough curves of $\mathrm{NH}_{4}-\mathrm{N}, \mathrm{Na}, \mathrm{K}, \mathrm{Ca}$, and $\mathrm{Mg}$ is shown in Figs. 5-9. The values of $\mathrm{r}^{2}$, RMSE, and NRMSE obtained from the cations leaching simulation are shown in Tables 7-9. The main mechanism to simulate the leaching of these cations is the cation exchange that controls the concentrations of the cations in leachates. The addition of organic amendments to soil increased CEC of soil columns, which was defined for different soil columns in the PHREEQC program. Some researchers also reported that the use of organic residues increased soil CEC (Ouedraogo et al., 2001; Walker \& Bernal, 2005; Clark et al., 2007). The results showed that $\mathrm{NH}_{4}-\mathrm{N}$ leaching was well predicted (Fig. 5) in soils treated with sewage sludge and poultry manure $\left(\mathrm{r}^{2}=0.84-0.97, \mathrm{RMSE}=1.23-24.11\right)$. But the simulation of NH4-N leaching in the control soil was not very accurate $\left(\mathrm{r}^{2}=0.61, \mathrm{RMSE}=0.14\right)$. The NH4-N curve tailing did not match well with the measured data in soil columns treated with $3 \%$ and $5 \%$ of sewage sludge, which may be due to mineralization and ammonification of sewage sludge over time. The breakthrough curves of Na were less accurate (Fig. 6) than the other cations $\left(\mathrm{r}^{2}=0.51-0.67, \mathrm{RMSE}=1.7-93.38\right)$, and the Na leaching was overestimated. The breakthrough curves of K (Fig. 7) and Ca (Fig. 8) indicated that K and Ca leaching in control soil and soils amended with sewage sludge and poultry manure were well predicted (High $\mathrm{r}^{2}$ and low RMSE). Simulation of Mg (Fig. 9) leaching showed that there was no good agreement between measured and simulated data in some treatments and the simulation had low accuracy. For a better comparison of cation simulation results, the NRMSE was calculated (Table 9). The NRMSE is used to compare models with different scales or with different observation values. NRMSE values, similar to RMSE, indicate that simulation of leaching of $\mathrm{NH}_{4}-\mathrm{N}, \mathrm{K}$, and $\mathrm{Ca}$ (mean NRMSE $<1$ ) by cation exchange model was better than $\mathrm{Mg}$ and $\mathrm{Na}$ (mean NRMSE > 1). Many studies have used PHREEQC program to simulate the adsorption, transport, and leaching of different elements (Ferrell et al., 2002; Komnitsas et al., 2006; Congzhi et al., 2006; Martens et al., 2011; Mazloomi \& Jalali, 2017; Jalali \& Latifi, 2018). Ferrel et al. (2002) used the PHREEQC program to predict lead $(\mathrm{Pb})$ transport in the clay layer of a landfill and simulated the effect of 
different parameters (CEC, selectivity coefficients, diffusion coefficient, and different amounts of $\mathrm{Pb}$ ) on $\mathrm{Pb}$ transport. Congzhi (2006) investigated the transport of $\mathrm{K}, \mathrm{Na}$, Ca, and $\mathrm{Mg}$ through soil column experiments and simulated the measured data using PHREEQC and CXTFIT programs. He reported that the simulation results were in good agreement with the measured data and PHREEQC simulated the measured data better than CXTFIT. Martens et al. (2011) measured leaching of K, Na, Ca, and Mg cations into the clay column over 2600 days (clay column was leached by different concentrations of sodium nitrate) and then simulated the measured results by PHREEQC program. They indicated that cation exchange is the predominant mechanism for control of cations leaching into the clay column.

\section{Conclusions}

Sewage sludge and poultry manure are widely used to provide nutrients for crops and improve soil quality. However, an excess application may increase the risk of nutrient loss and groundwater pollution. Since our research was performed in the laboratory, which does not exactly replicate conditions in the field, we were able to determine the relative risk of leaching among the tested organic amendments. The content of nutrients and the application rate of sewage sludge and poultry manure were influential factors on the values of leaching of nutrients. The maximum value of $\mathrm{NH}_{4}-\mathrm{N}$ leaching was observed in the soil columns amended with $5 \%$ sewage sludge and the maximum values of $\mathrm{NO}_{3}-\mathrm{N}, \mathrm{Na}, \mathrm{K}, \mathrm{Ca}$ and $\mathrm{Mg}$ leaching were observed in the columns amended with $5 \%$ poultry manure. In general, the order of nutrients leached in sewage sludgeamended soils was $\mathrm{NH}_{4}-\mathrm{N}>\mathrm{NO}_{3}-\mathrm{N}>\mathrm{Mg}>\mathrm{Na}>\mathrm{K}>\mathrm{Ca}$, whereas the order for poultry-amended soils was $\mathrm{K}>\mathrm{NO}_{3}-\mathrm{N}>\mathrm{Na}>\mathrm{NH}_{4}-\mathrm{N}>\mathrm{Mg}>\mathrm{Ca}$, indicating the potential risk of soil nutrient leaching, especially $\mathrm{NH}_{4}-\mathrm{N}, \mathrm{K}$ and $\mathrm{NO}_{3}-\mathrm{N}$ posed after application of sewage sludge and poultry manure, respectively, should be given greater attention. The output of the PHREEQC program showed that the simulated breakthrough curves, particularly for $\mathrm{NH}_{4}-\mathrm{N}, \mathrm{K}$, and Ca were well matched to the measured data. The main mechanism to simulate the leaching of these cations was the cation exchange that controls the concentration of the cations in leachates.

\section{References}

Adegbidi, H. G., Briggs, R. D., Volk, T. A., White, E. H., \& Abrahamson, L. P. (2003). Effect of organic amendments and slow-release nitrogen fertilizer on willow biomass production and soil chemical characteristics. Biomass and Bioenergy, 25, 389-398.

Ahlberg, G., Gustafsson, O., \& Wedel, P. (2006). Leaching of metals from sewage sludge during one year and their relationship to particle size. Environmental Pollution, 144, 545-553.

Angelova, V. R., Akova, V. I., Artinova, N. S., \& Ivanov, K. I. (2013). The effect of organic amendments on soil chemical characteristics. Bulgarian Journal of Agricultural Science, 19, 958-971.

Appelo, C. A. J., \& Postma, D. (1993). Geochemistry, groundwater, and pollution: Rotterdam. AA Balkema, 536(2), 237-247.

Aronsson, H., Liu, J., Ekre, E., Torstensson, G., \& Salomo, E. (2014). Effects of pig and dairy slurry application on $\mathrm{N}$ and $\mathrm{P}$ leaching from crop rotations with spring cereals and forage leys. Nutrient Cycling in Agroecosystems, 98, 281-293.

Atiyeh, R. M., Edwards, C. A., Subler, S., \& Metzger, J. D. (2001). Pig manure vermicompost as a component of a horticultural bedding plant medium: effects on physicochemical properties and plant growth. Bioresource Technology, 78, 11-20.

Brady, N. C., \& Weil, R. R. (2012). The Nature and Properties of Soils revised fourteenth ed. Dorling Kindersley (India) Pvt. Ltd., New Delhi, 110017.

Bramryd, T. (2002). Impact of sewage sludge application on the long-term nutrient balance in acid soils of Scots pine (Pinus sylvestris, L.) forests. Water, Air, and Soil Pollution, 140, 381-399. 
Breland, T. A., \& Hansen, S. (1996). Nitrogen mineralization and microbial biomass as affected by soil compaction. Soil Biology and Biochemistry, 28, 655-663.

Brockway, D. G. (1983). Forest, floor, soil, and vegetation responses to sludge fertilization in Red and White pine plantation. Science Society American Journal, 47, 776- 784.

Brookes, P. C., \& McGrath, S. P. (1984). Effect of metal toxicity on the size of the soil microbial biomass. European Journal of Soil Science, 35, 341-346.

Butterly, C. R., Baldock, J. A., \& Tang, C. (2013). The contribution of crop residues to changes in soil pH under field conditions. Plant and Soil, 366, 185-198.

Cameron, K. C., Rate, A. W., Carey, P. L., \& Smith, N. P. (1995). Fate of nitrogen in pig effluent applied to a shallow stony pasture soil. New Zealand Journal of Agricultural Research, 38, 533-542.

Cameron, K. C., Rate, A. W., Noonan, M. J., Moore, S., Smith, N. P., \& Kerr, L. E. (1996). Lysimeter study of the fate of nutrients following subsurface injection and surface application of dairy pond sludge to pasture. Agriculture, Ecosystems, and Environment, 58, 187-197.

Carey, P. L., Rate, A. W., \& Cameron, K. C. (1997). Fate of nitrogen in pig slurry applied to a New Zealand pasture soil. Soil Research, 35, 941-959.

Civeira, G., \& Lavado, R. S. (2008). Nitrate losses, nutrients and heavy metal accumulation from substrates assembled for urban soils reconstruction. Journal of Environmental Management, 88, 1619-1623.

Clark, G. J., Dodgshun, N., Sale, P. W. G., \& Tang, C. (2007). Changes in chemical and biological properties of a sodic clay subsoil with addition of organic amendments. Soil Biology and Biochemistry, 39, 2806-2817.

Congzhi, Z., Shaohui, X., \& Jiabao, Z. (2006). Application of a solute transport model coupled with chemical reaction. Acta Pedologica Sinica, 43, 910-917.

Correa, R. S., White, R. E., \& Weatherley, A. J. (2006). Effect of compost treatment of sewage sludge on nitrogen behavior in two soils. Waste Management, 26(6), 614-619.

Deare, F. M., Ahmad, N., \& Ferguson, T. U. (1995). Downward movement of nitrate and ammonium nitrogen in a flatland ultisol. Nutrient Cycling in Agroecosystems, 42, 175-184.

Di, H. J., \& Cameron, K. C. (2005). Reducing environmental impacts of agriculture by using a fine particle suspension nitrification inhibitor to decrease nitrate leaching from grazed pastures. Agriculture, Ecosystems and Environment, 109, 202-212.

Elmi, A., Madani, A., Gordon, R., MacDonald, P., \& Stratton, G. W. (2005). Nitrate nitrogen in the soil profile and drainage water as influenced by manure and mineral fertilizer application in a barley-carrot production system. Water, Air and Soil Pollution, 160, 119-132.

Embile, R., Walder, I., \& Mahoney, J., (2019). Multicomponent reactive transport modeling of effluent chemistry using locally obtained mineral dissolution rates of forsterite and pyrrhotite from a mine tailings deposit. Advances in Water Resources. 128, 87-96.

Evangelou, V. P., \& Lumbanraja, J. (2002). Ammonium-potassium-calcium exchange on vermiculite and hydroxy-aluminum vermiculite. Soil Science Society of America Journal, 66, 445-455.

Ferrell, R. E., Aagaard, P., Forsman, J., Greenwood, L., \& Zheng, Z. (2002). Application of a geochemical transport model to predict heavy metal retention $(\mathrm{Pb})$ by clay liners. Applied Clay Science, 21, 59-66.

Forge, T., Kenney, E., Hashimoto, N., Neilsen, D., \& Zebarth, B. (2016). Compost and poultry manure as preplant soil amendments for red raspberry: Comparative effects on root lesion nematodes, soil quality and risk of nitrate leaching. Agriculture, Ecosystems and Environment, 223, 48-58. 
Gallardo-Lara, F., \& Nogales, R. (1987). Effect of the application of town refuse compost on the soil-plant system: A review. Biological Wastes, 19, 35-62.

Gondek, K., Kopieć, M., \& Kaczmarczyk, M. (2009). Nitrogen Content in Maize and Soils Fertilized with Organic Materials. Ecological Chemistry and Engineering. A, 16, 555-566.

González, C. E. A., Gil, E., Fernández-Falcón, M., \& Hernández, M. M. (2009). Water leachates of nitrate nitrogen and cations from poultry manure added to an alfisol udalf soil. Water, Air, and Soil Pollution, 202, 273-288.

Gonzalez, M., Gomez, E., Comese, R., Quesada, M., \& Conti, M. (2010). Influence of organic amendments on soil quality potential indicators in an urban horticultural system. Bioresource Technology, 101, 8897-8901.

Gundersen, P. (1998). Effects of enhanced nitrogen deposition in a spruce forest at Klosterhede, Denmark, examined by moderate NH4NO3 addition. Forest Ecology and Management, 101, 251-268.

Haynes, R. J., \& Judge, A. (2008). Influence of surface-applied poultry manure on topsoil and subsoil acidity and salinity: A leaching column study. Journal of Plant Nutrition and Soil Science, 171, 370-377.

Herrmann, M., Pust, J., \& Pott, R. (2005). Leaching of nitrate and ammonium in heathland and forest ecosystems in Northwest Germany under the influence of enhanced nitrogen deposition. Plant and Soil, 273, 129-137.

Hesse, P. R., \& Hesse, P. R. (1971). A textbook of soil chemical analysis. Chemical Publishing Co. Inc., New York, 520 p.

Ingraham, P. A., \& William A. (2019). Salas Assessing nitrous oxide and nitrate leaching mitigation potential in US corn crop systems using the DNDC model. Agricultural Systems 175, 79-87.

Islam, M. R., Mao, S., Xue, X., Eneji, A. E., Zhao, X., \& Hu, Y. (2011). A lysimeter study of nitrate leaching, optimum fertilisation rate and growth responses of corn (Zea mays L.) following soil amendment with water-saving super-absorbent polymer. Journal of the Science of Food and Agriculture, 91, 1990-1997.

Jalali, M. (2005). Nitrates leaching from agricultural land in Hamadan, western Iran. Agriculture, Ecosystems and Environment, 110, 210-218.

Jalali, M., \& Latifi, Z. (2018). Measuring and simulating effect of organic residues on the transport of cadmium, nickel, and zinc in a calcareous soil. Journal of Geochemical Exploration, 184, 372-380.

Jalali, M., \& Merrikhpour, H. (2008). Effects of poor quality irrigation waters on the nutrient leaching and groundwater quality from sandy soil. Environmental Geology, 53, 1289-1298.

Jones, B. E., Haynes, R. J., \& Phillips, I. R. (2012). Cation and anion leaching and growth of Acacia saligna in bauxite residue sand amended with residue mud, poultry manure and phosphogypsum. Environmental Science and Pollution Research, 19, 835-846.

Komnitsas, K., Bartzas, G., \& Paspaliaris, I. (2004). Efficiency of limestone and red mud barriers: laboratory column studies. Minerals Engineering, 17, 183-194.

Li, Y. C., Stoffella, P. J., Alva, A. K., Calvert, D. V., \& Graetz, D. A. (1997). Leaching of nitrate, ammonium, and phosphate from compost amended soil columns. Compost Science and Utilization, 5, 63-67.

Li, P., Lang, M., Li, C., Thomas, B.W., \& Hao, X. (2016). Nutrient leaching from soil amended with manure and compost from cattle fed diets containing wheat dried distillers'grains with solubles. Water Air and Soil Pollution, 227, 393.

Martens, E., Jacques, D., Wang, L., De Canniere, P., Van Gompel, M., Marien, A., \& Valcke, E. (2011). Modelling of cation concentrations in the outflow of NaNO 3 percolation experiments through Boom Clay cores. Physics and Chemistry of the Earth, Parts A/B/C, 36, 1693-1699. 
Masaka, J., Wuta, M., Nyamangara, J., \& Mugabe, F. T. (2013). Effect of manure quality on nitrate leaching and groundwater pollution in wetland soil under field tomato (Lycopersicon esculentum, Mill var. Heinz) rape (Brassica napus, L var. Giant). Nutrient Cycling in Agroecosystems, 96, 149-170.

Mazloomi, F., and Jalali, M. (2017). Adsorption of ammonium from simulated wastewater by montmorillonite nanoclay and natural vermiculite: experimental study and simulation. Environmental monitoring and assessment, 189(8), 415.

Mazloomi, F., \& Jalali, M. (2019). Effects of vermiculite, nanoclay and zeolite on ammonium transport through saturated sandy loam soil: Column experiments and modeling approaches. Catena, 176, 170-180.

Mazur, T. (1993). Nawożenie jako czynnik zakwaszenia gleb użytkowanych rolniczo. Sympozjum naukowe " Przyrodnicze i antropogeniczne przyczyny oraz skutki zakwaszenia gleb ". Lublin, 21-22.

McLaren, R. G., Clucas, L. M., Taylor, M. D., \& Hendry, T. (2003). Leaching of macronutrients and metals from undisturbed soils treated with metal-spiked sewage sludge. 1. Leaching of macronutrients. Soil Research, 41, 571-588.

Medalie, L., Bowden, W. B., \& Smith, C. T. (1994). Nutrient leaching following land application of aerobically digested municipal sewage sludge in a northern hardwood forest. Journal of Environmental Quality, 23, $130-138$.

Mulvaney, R. L. (1996). Nitrogen-inorganic forms. In 'Methods of soil analysis. Part 3. Chemical methods'.(Eds DL Sparks, AL Page, PA Helmke, RH Loeppert, PN Soltanpour, MA Tabatabai, CT Johnston, ME Sumner). Soil Science Society of America Inc Madison WI, 1123-1184.

Niklasch, H., \& Joergensen, R. G. (2001). Decomposition of peat, biogenic municipal waste compost, and shrub/grass compost added in different rates to a silt loam. Journal of Plant Nutrition and Soil Science, 164, 365-369.

Oren, A. (2002). Diversity of halophilic microorganisms: environments, phylogeny, physiology, and applications. Journal of Industrial Microbiology and Biotechnology, 28, 56-63.

Ouédraogo, E., Mando, A., \& Zombré, N. P. (2001). Use of compost to improve soil properties and crop productivity under low input agricultural system in West Africa. Agriculture, Ecosystems and Environment, 84, 259-266.

Parkhurst, D. L., \& Appelo, C. A. J. (2013). Description of input and examples for PHREEQC version 3: a computer program for speciation, batch-reaction, one-dimensional transport, and inverse geochemical calculations (No. 6-A43). US Geological Survey.

Parvage, M. M., Ulen, B., \& Kirchmann, H. (2015). Nutrient leaching from manure-amended topsoils (Cambisols and Histosols) in Sweden. Geoderma Regional, 5, 209-214.

Pathan, S. M., Aylmore, L. A. G., \& Colmer, T. D. (2002). Reduced leaching of nitrate, ammonium, and phosphorus in a sandy soil by fly ash amendment. Soil Research, 40, 1201-1211.

Paul, K. I., Black, A. S., \& Conyers, M. K. (2003). Development of acidic subsurface layers of soil under various management systems. Advances in Agronomy, 78, 187-214.

Pocknee, S., \& Sumner, M. E. (1997). Cation and nitrogen contents of organic matter determine its soil liming potential. Soil Science Society of America Journal, 61, 86-92.

Qiang, Z., Speir, T. W., \& van Schaik, A. P. (2004). Leaching of nutrients from soil cores treated with a single large dose of digested sewage sludge. Biology and Fertility of Soils, 40, 284-289.

Razzaque, A. H. M., \& Hanafi, M. M. (2005). Leaching of nitrogen in peat soil. Communications in Soil Science and Plant Analysis, 35, 1793-1799. 
Sądej, W., Bowszys, T., \& Namiotko, A. (2009). Leaching of Nitrogen Forms from Soil Fertilized with Sewage Sludge. Ecological Chemistry and Engineering. A, 16, 1001-1008.

Samaras, V., Tsadilas, C. D., \& Stamatiadis, S. (2008). Effects of repeated application of municipal sewage sludge on soil fertility, cotton yield, and nitrate leaching. Agronomy Journal, 100(3), 477-483.

Sarwar, G., Hussain, N., Mujeeb, F., Schmeisky, H., \& Hassan, G. (2003). Biocompost application for the improvement of soil characteristics and dry matter yield of Lolium perenne (Grass). Asian Journal of Plant Science, 2, 237-241.

Selvakumari, G., Baskar, M., Jayanthi, D., \& Mathan, K. K. (2000). Effect of integration of fly ash with fertilizers and organic manures on nutrient availability, yield and nutrient uptake of rice in Alfisols. Journal of the Indian Society of Soil Science, 48, 268-278.

Sharpley, A., Kleinman, P., \& Weld, J. (2004). Assessment of best management practices to minimise the runoff of manure-borne phosphorus in the United States. New Zealand journal of agricultural research, 47, 461-477.

Shepherd, M. A. (1996). Factors affecting nitrate leaching from sewage sludges applied to a sandy soil in arable agriculture. Agriculture, ecosystems and environment, 58(2-3), 171-185.

Shepherd, M., \& Newell-Price, P. (2013). Manure management practices applied to a seven-course rotation on a sandy soil: effects on nitrate leaching. Soil Use and Management, 29, 210-219.

Stenger, R., Priesack, E., \& Beese, F. (1995). Rates of net nitrogen mineralization in disturbed and undisturbed soils. Plant and Soil, 171, 323-332.

Thorburn, P. J., Biggs, J. S., Weier, K. L., \& Keating, B. A. (2003). Nitrate in groundwaters of intensive agricultural areas in coastal Northeastern Australia. Agriculture, Ecosystems and Environment, 94, 49-58.

Tong, Y. A., Emteryd, O., Lu, D. Q., \& Grip, H. (1997). Effect of organic manure and chemical fertilizer on nitrogen uptake and nitrate leaching in a Eum-orthic anthrosols profile. Nutrient Cycling in Agroecosystems, $48,225-229$.

Walker, D. J., \& Bernal, M. P. (2005). Plant mineral nutrition and growth in a saline Mediterranean soil amended with organic wastes. Communications in Soil Science and Plant Analysis, 35, 2495-2514.

Wang, F. L., \& Bettany, J. R. (1995). Carbon and nitrogen losses from undisturbed soil columns under short-term flooding conditions. Canadian Journal of Soil Science, 75, 333-341.

Wang, Y., \& Zhang, Y. P. (2004). $\mathrm{NH}_{4}{ }^{+}$adsorption in a Eum-Orthic Anthrosol at different solution/soil ratios and temperatures. Pedosphere, 14, 253-257.

Xiong, Y., Huang, G., \& Huang, Q. (2006). Modeling solute transport in one-dimensional homogeneous and heterogeneous soil columns with continuous time random walk. Journal of Contaminant Hydrology, 86, $163-175$.

Zarabi, M., \& Jalali, M. (2012). Leaching of nitrogen from calcareous soils in western Iran: a soil leaching column study. Environmental Monitoring and Assessment, 184, 7607-7622.

Zhang, M. K., He, Z. L., Calvert, D. V., \& Stoffella, P. J. (2004). Leaching of minerals and heavy metals from muck-amended sandy soil columns1. Soil Science, 169, 528-540.

Table 1 . Some physical and chemical properties of soil.

\begin{tabular}{lllllll}
\hline $\mathrm{NH}_{4}-\mathrm{N}(\mathrm{mg} / \mathrm{kg})$ & $\mathrm{NO}_{\mathbf{3}}-\mathrm{N}(\mathrm{mg} / \mathrm{kg})$ & Total N (\%) & $\mathrm{OM}(\%)$ & $\mathrm{CaCO}_{3}$ equivalent $(\%)$ & $\mathrm{EC}(\mathrm{dS} / \mathrm{m})$ & $\mathrm{pH}\left(\mathrm{H}_{2}\right.$ \\
\hline 5.4 & 10.2 & 0.2 & 3.7 & 4.7 & 0.2 & 7.1 \\
\hline
\end{tabular}


Table 2. Characteristics of organic sewage sludge and poultry manure.

\begin{tabular}{|c|c|c|}
\hline Characteristics & Sewage sludge & Poultry manure \\
\hline $\mathrm{pH}$ & 6.83 & 7.27 \\
\hline EC $(\mathbf{d S} / \mathbf{m})$ & 4.95 & 12.72 \\
\hline Total N (\%) & 3.05 & 1.47 \\
\hline C (\%) & 19.45 & 28.35 \\
\hline $\mathrm{C} / \mathrm{N}$ & 6.40 & 19.28 \\
\hline $\mathrm{NH}_{4}-\mathrm{N}(\mathrm{mg} / \mathrm{kg})$ & 4760 & 780 \\
\hline $\mathrm{NO}_{3}-\mathrm{N}(\mathrm{mg} / \mathrm{kg})$ & 299 & 595 \\
\hline Total Na (mg/g) & 2.10 & 10.20 \\
\hline Total K (mg/g) & 4.50 & 48.60 \\
\hline Total Ca (mg/g) & 42.10 & 37.80 \\
\hline Total Mg (mg/g) & 11.40 & 14.00 \\
\hline Exchangeable $\mathrm{Na}\left(\mathrm{cmol}_{\mathrm{c}} / \mathrm{kg}\right)$ & 1.12 & 6.90 \\
\hline Exchangeable $\mathrm{K}\left(\mathrm{cmol}_{\mathrm{c}} / \mathrm{kg}\right)$ & 0.59 & 0.64 \\
\hline Exchangeable $\mathrm{Ca}\left(\mathrm{cmol}_{\mathrm{c}} / \mathrm{kg}\right)$ & 42.40 & 34.00 \\
\hline Exchangeable $\mathrm{Mg}\left(\mathrm{cmol}_{\mathrm{c}} / \mathrm{kg}\right)$ & 12.00 & 6.00 \\
\hline
\end{tabular}

Table 3. The amount of exchangeable and soil solution characteristics in control and amended soils with different rates of applied sewage sludge and poultry manure.

\begin{tabular}{lllll}
\hline Parameter & Control soil & Sewage sludge 1\% & Sewage sludge 3\% & Sewage sludge 5\% \\
\hline & Exchangeable cations & Exchangeable cations & Exchangeable cations & Exchangeable cati \\
$\mathbf{N H}_{\mathbf{4}}\left(\mathbf{c m o l}_{\mathbf{c}} / \mathbf{k g}\right)$ & $0.03 \mathrm{e}$ & $0.2 \mathrm{~d}$ & $0.6 \mathrm{c}$ & $1.2 \mathrm{a}$ \\
$\mathbf{N a ~}\left(\mathbf{c m o l}_{\mathbf{c}} / \mathbf{k g}\right)$ & $0.6 \mathrm{c}$ & $0.6 \mathrm{c}$ & $0.7 \mathrm{bc}$ & $0.7 \mathrm{bc}$ \\
$\mathbf{K}\left(\mathbf{c m o l}_{\mathbf{c}} / \mathbf{k g}\right)$ & $1.7 \mathrm{c}$ & $1.8 \mathrm{c}$ & $2.1 \mathrm{ab}$ & $2.1 \mathrm{ab}$ \\
$\mathbf{C a}\left(\mathbf{c m o l}_{\mathbf{c}} / \mathbf{k g}\right)$ & $8.3 \mathrm{f}$ & $8.7 \mathrm{e}$ & $9.4 \mathrm{c}$ & $10.2 \mathrm{a}$ \\
$\mathbf{M g}\left(\mathbf{c m o l}_{\mathbf{c}} / \mathbf{k g}\right)$ & $2.6 \mathrm{~d}$ & $2.7 \mathrm{~cd}$ & $2.9 \mathrm{~b}$ & $3.1 \mathrm{a}$ \\
& Soil solution & Soil solution & Soil solution & Soil solution \\
$\mathbf{p H}$ & $7.42 \mathrm{~b}$ & $7.45 \mathrm{~b}$ & $7.40 \mathrm{bc}$ & $7.30 \mathrm{c}$ \\
$\mathbf{E C ~}(\mathbf{d S} / \mathbf{m})$ & $1.19 \mathrm{~g}$ & $1.67 \mathrm{f}$ & $2.10 \mathrm{e}$ & $3.15 \mathrm{c}$ \\
$\mathbf{N H}(\mathbf{m M})$ & $0.02 \mathrm{e}$ & $0.41 \mathrm{c}$ & $0.78 \mathrm{~b}$ & $0.95 \mathrm{a}$ \\
$\mathbf{N O}(\mathbf{m M})$ & $0.07 \mathrm{~d}$ & $0.19 \mathrm{c}$ & $0.42 \mathrm{~b}$ & $0.83 \mathrm{a}$ \\
$\mathbf{N a}(\mathbf{m M})$ & $2.45 \mathrm{f}$ & $2.75 \mathrm{ef}$ & $2.90 \mathrm{de}$ & $3.15 \mathrm{~cd}$ \\
$\mathbf{K}(\mathbf{m M})$ & $2.67 \mathrm{f}$ & $3.05 \mathrm{ef}$ & $3.40 \mathrm{de}$ & $3.70 \mathrm{~d}$ \\
$\mathbf{C a}(\mathbf{m M})$ & $7.80 \mathrm{f}$ & $10.90 \mathrm{e}$ & $13.10 \mathrm{~d}$ & $15.20 \mathrm{c}$ \\
$\mathbf{M g}(\mathbf{m M})$ & $3.20 \mathrm{f}$ & $4.70 \mathrm{e}$ & $7.20 \mathrm{c}$ & $10.40 \mathrm{a}$ \\
\hline
\end{tabular}

Means followed by dissimilar letters within a row are significantly different at $\mathrm{p}<0.05$ according to Duncan test.

Table 4. Selectivity coefficients values used to simulate leaching of cations in control and amended soils with rates of $1 \%, 3 \%$ and $5 \%$ sewage sludge and poultry manure.

\begin{tabular}{|c|c|c|c|c|}
\hline $\mathrm{Mg}^{2+}+2 \mathrm{X}^{-}=\mathrm{MgX}_{2}$ & $\mathrm{Ca}^{2+}+2 \mathrm{X}^{-}=\mathrm{CaX}_{2}$ & $\mathbf{K}^{+}+\mathbf{X}^{-}=\mathbf{K X}$ & $\mathbf{N a}^{+}+\mathbf{X}^{-}=\mathbf{N a X}$ & $\mathbf{A m m H}^{+}+\mathbf{X}^{-}=\mathbf{A m}$ \\
\hline 1.60 & 2.10 & 2.20 & 2.20 & 2.20 \\
\hline 1.00 & 1.30 & 1.50 & 1.20 & 0.70 \\
\hline 0.60 & 0.80 & 0.90 & 0.60 & 0.40 \\
\hline
\end{tabular}




\begin{tabular}{lllll}
\hline $\mathbf{M g}^{\mathbf{2}}+\mathbf{2 X}^{-}=\mathbf{M g X}$ & $\mathbf{C a}^{\mathbf{2}+}+\mathbf{2 \mathbf { X } ^ { - }}=\mathbf{C a X}_{\mathbf{2}}$ & $\mathbf{K}^{+}+\mathbf{X}^{-}=\mathbf{K X}$ & $\mathbf{N a}^{+}+\mathbf{X}^{-}=\mathbf{N a X}$ & $\mathbf{A m m H}^{+}+\mathbf{X}^{-}=\mathbf{A m}$ \\
\hline 0.60 & 0.80 & 0.70 & 0.70 & 0.30 \\
0.90 & 1.40 & 0.70 & 0.70 & 0.90 \\
0.30 & 0.40 & 0.30 & 0.00 & 0.30 \\
0.60 & 0.80 & 0.20 & 0.00 & 0.40 \\
\hline
\end{tabular}

Table 5. The cumulative amounts of nutrients leached from control and amended soils with rates of $1 \%$, $3 \%$ and $5 \%$ sewage sludge and poultry manure.

\begin{tabular}{llllll}
\hline nutrients & Control soil & Sewage sludge $\mathbf{1 \%}$ & Sewage sludge $\mathbf{3 \%}$ & Sewage sludge $\mathbf{5 \%}$ & Poultry manure $\mathbf{1 \%}$ \\
\hline $\mathbf{N H}_{\mathbf{4}}$ & $0.27 \mathrm{f}$ & $10.20 \mathrm{de}$ & $46.17 \mathrm{~b}$ & $93.32 \mathrm{a}$ & $3.87 \mathrm{ef}$ \\
$\mathbf{N O}_{\mathbf{3}}$ & $3.00 \mathrm{~d}$ & $8.40 \mathrm{~cd}$ & $12.80 \mathrm{c}$ & $20.29 \mathrm{~b}$ & $9.04 \mathrm{~cd}$ \\
$\mathbf{N a}$ & $4.47 \mathrm{f}$ & $15.70 \mathrm{e}$ & $38.64 \mathrm{~d}$ & $64.85 \mathrm{c}$ & $69.19 \mathrm{c}$ \\
$\mathbf{K}$ & $19.25 \mathrm{e}$ & $22.5 \mathrm{e}$ & $42.12 \mathrm{~d}$ & $54.81 \mathrm{~cd}$ & $69.06 \mathrm{c}$ \\
$\mathbf{C a}$ & $87.84 \mathrm{f}$ & $103.60 \mathrm{e}$ & $131.10 \mathrm{~d}$ & $152.70 \mathrm{~b}$ & $91.46 \mathrm{f}$ \\
$\mathbf{M g}$ & $33.96 \mathrm{~b}$ & $39.84 \mathrm{~b}$ & $37.24 \mathrm{~b}$ & $58.49 \mathrm{a}$ & $40.33 \mathrm{~b}$ \\
\hline
\end{tabular}

Means followed by dissimilar letters within a row are significantly different at $\mathrm{p}<0.05$ according to Duncan test.

Table 6. Pearson correlation coefficients between cumulative leaching amounts of $\mathrm{NH}_{4}, \mathrm{NO}_{3}, \mathrm{Na}, \mathrm{K}, \mathrm{Ca}$, and $\mathrm{Mg}$ and their exchangeable and solutions in control and amended soil.

\begin{tabular}{lllll}
\hline & & Cumulative nutrients leached & Cumulative nutri \\
\hline \multirow{3}{*}{ Exchangeable cations } & \multirow{2}{*}{ Exchangeable cations } & $\mathbf{N H}_{4}$ & $\mathbf{N H}_{4}-\mathbf{N}$ & $\mathbf{N H}_{4}-\mathbf{N}$ \\
& & $\mathbf{N a}$ & $\mathbf{N a}$ & $0.92^{* *}$ \\
& & $\mathbf{K}$ & $\mathbf{K}$ & 0.13 \\
& & $\mathbf{C a}$ & $\mathbf{C a}$ & 0.58 \\
Soil solution properties & Soil solution properties & $\mathbf{M g}$ & $\mathbf{M g}$ & $0.92^{* *}$ \\
& & $\mathbf{p H}$ & $\mathbf{p H}$ & $0.77^{*}$ \\
& & $\mathbf{E C}$ & $\mathbf{E C}$ & -0.44 \\
& & $\mathbf{N H}$ & $\mathbf{N H}$ & 0.30 \\
& & $\mathbf{N O}$ & $\mathbf{N O}$ & $0.87^{* *}$ \\
& & $\mathbf{N a}$ & $\mathbf{N a}$ & $0.99^{* *}$ \\
& & $\mathbf{K}$ & $\mathbf{K}$ & 0.46 \\
& & $\mathbf{C a}$ & $\mathbf{C a}$ & 0.01 \\
& $\mathbf{M g}$ & $\mathbf{M g}$ & 0.39 \\
& & & & $0.85^{* *}$ \\
\hline
\end{tabular}

*significant at $5 \%$ level, ${ }^{* *}$ significant at $1 \%$ level.

Table 7. Determination coefficient $\left(\mathrm{r}^{2}\right)$ values obtained from simulation of cations leaching in in control and amended soils with rates of $1 \%, 3 \%$ and $5 \%$ sewage sludge and poultry manure.

\begin{tabular}{llllllll}
\hline $\mathbf{M g}$ & $\mathbf{M g}$ & $\mathbf{C a}$ & $\mathbf{C a}$ & $\mathbf{K}$ & $\mathbf{N a}$ & $\mathbf{N H}_{\mathbf{4}}-\mathbf{N}$ & Soil Columns \\
\hline 0.69 & 0.81 & 0.81 & 0.95 & 0.95 & 0.61 & 0.61 & Control soil \\
0.30 & 0.72 & 0.72 & 0.79 & 0.79 & 0.64 & 0.84 & Sewage sludge 1\%
\end{tabular}




\begin{tabular}{llllllll}
\hline $\mathbf{M g}$ & $\mathbf{M g}$ & $\mathbf{C a}$ & $\mathbf{C a}$ & $\mathbf{K}$ & $\mathbf{N a}$ & $\mathbf{N H}_{\mathbf{4}}-\mathbf{N}$ & Soil Columns \\
\hline 0.54 & 0.83 & 0.83 & 0.81 & 0.81 & 0.51 & 0.91 & Sewage sludge 3\% \\
0.74 & 0.77 & 0.77 & 0.79 & 0.79 & 0.58 & 0.90 & Sewage sludge 5\% \\
0.72 & 0.89 & 0.89 & 0.85 & 0.85 & 0.67 & 0.88 & Poultry manure 1\% \\
0.74 & 0.88 & 0.88 & 0.94 & 0.94 & 0.57 & 0.97 & Poultry manure 3\% \\
0.29 & 0.92 & 0.92 & 0.83 & 0.83 & 0.63 & 0.86 & Poultry manure 5\% \\
\hline
\end{tabular}

Table 8. Root-mean-square error (RMSE) values obtained from simulation of cations leaching in in control and amended soils with rates of $1 \%, 3 \%$ and $5 \%$ sewage sludge and poultry manure.

\begin{tabular}{llllll}
\hline $\mathrm{Mg}$ & $\mathrm{Ca}$ & $\mathrm{K}$ & $\mathrm{Na}$ & $\mathrm{NH}_{4}-\mathrm{N}$ & Soil Columns \\
\hline 33.19 & 54.30 & 4.09 & 1.70 & 0.14 & Control soil \\
34.08 & 70.52 & 13.71 & 7.73 & 3.77 & Sewage sludge 1\% \\
28.25 & 62.15 & 26.43 & 16.17 & 12.40 & Sewage sludge 3\% \\
26.11 & 71.55 & 39.36 & 28.03 & 24.11 & Sewage sludge 5\% \\
40.40 & 61.10 & 29.70 & 22.20 & 1.23 & Poultry manure 1\% \\
29.14 & 70.79 & 73.89 & 54.00 & 3.37 & Poultry manure 3\% \\
43.79 & 57.12 & 209.97 & 93.38 & 10.22 & Poultry manure 5\% \\
\hline
\end{tabular}

Table 9. Normalized Root Mean Square Error (NRMSE) values obtained from simulation of cations leaching in control and amended soils with rates of $1 \%, 3 \%$ and $5 \%$ sewage sludge and poultry manure.

\begin{tabular}{llllll}
\hline $\mathbf{M g}$ & $\mathbf{C a}$ & $\mathbf{K}$ & $\mathbf{N a}$ & $\mathbf{N H}_{\mathbf{4}}-\mathbf{N}$ & Soil Columns \\
\hline 1.18 & 0.71 & 0.31 & 2.86 & 0.74 & Control soil \\
1.27 & 1.01 & 0.90 & 3.70 & 0.54 & Sewage sludge 1\% \\
1.12 & 0.70 & 0.93 & 3.16 & 0.40 & Sewage sludge 3\% \\
0.66 & 0.69 & 1.06 & 3.26 & 0.39 & Sewage sludge 5\% \\
1.48 & 0.99 & 0.64 & 2.42 & 0.47 & Poultry manure 1\% \\
0.66 & 0.75 & 0.47 & 1.95 & 0.30 & Poultry manure 3\% \\
0.90 & 0.52 & 0.82 & 2.11 & 0.43 & Poultry manure 5\% \\
1.03 & 0.76 & 0.73 & 2.78 & 0.47 & Mean \\
\hline
\end{tabular}

\section{Hosted file}

Figure.pdf available at https://authorea.com/users/333594/articles/459755-measuring-andsimulating-leaching-of-nutrients-from-a-calcareous-soil-amended-with-sewage-sludge-andpoultry-manure 
(a)
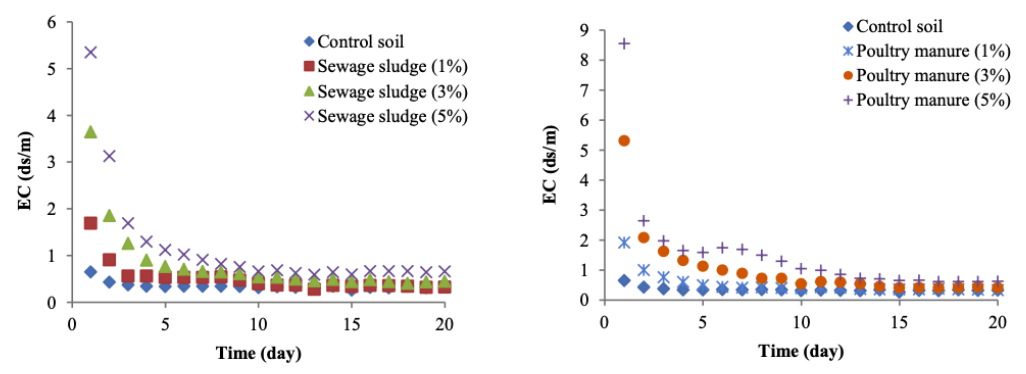

(b)
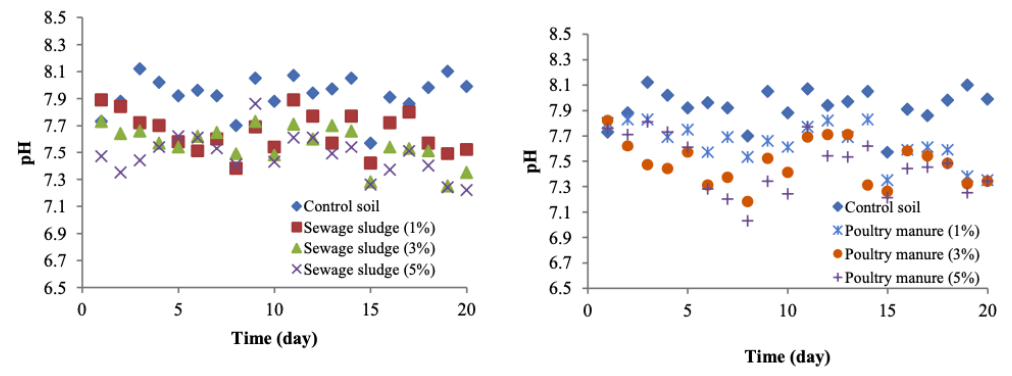